\title{
Autologous Bone-Marrow vs. Peripheral Blood Mononuclear Cells Therapy for Peripheral Artery Disease in Diabetic Patients
}

\author{
Em Yunir ${ }^{1,2}$, Farid Kurniawan ${ }^{1,2}$, Edo Rezaprasga ${ }^{1,2}$, Ika Prasetya Wijaya ${ }^{1}$, Indrati Suroyo ${ }^{3}$, \\ Sahat Matondang, Cosphiadi Irawan ${ }^{1}$, Pradana Soewondo ${ }^{1,2}$ \\ ${ }^{I}$ Department of Internal Medicine, Dr. Cipto Mangunkusumo National General Hospital, Faculty of Medicine Universitas Indonesia, \\ Fakarta, Indonesia \\ ${ }^{2}$ Metabolic Disorder, Cardiovascular, and Aging Cluster, Indonesian Medical Education and Research Institute, Faculty of Medicine \\ Universitas Indonesia, Fakarta, Indonesia \\ ${ }^{3}$ Department of Radiology, Dr. Cipto Mangunkusumo National General Hospital, Faculty of Medicine Universitas Indonesia, Fakarta, \\ Indonesia
}

Diabetes mellitus (DM) remains one of the most important risk factors for peripheral artery disease (PAD), with approximately $20 \%$ of DM patients older than 40 years old are affected with PAD. The current standard management for severe PAD is endovascular intervention with or without surgical bypass. Unfortunately, up to $40 \%$ of patients are unable to undergo these revascularization therapies due to excessive surgical risk or adverse vascular side effects. Stem cell therapy has emerged as a novel therapeutic strategy for these 'no-option' patients. Several types of stem cells are utilized for PAD therapy, including bone marrow mononuclear cells (BMMNC) and peripheral blood mononuclear cells (PBMNC). Many studies have reported the safety of BMMNC and PBMNC, as well as its efficacy in reducing ischemic pain, ulcer size, pain-free walking distance, ankle-brachial index (ABI), and transcutaneous oxygen pressure (TcPO2). However, the capacity to establish the efficacy of reducing major amputation rates, amputation free survival, and all-cause mortality is limited, as shown by several randomized placebo-controlled trials. The present literature review will focus on comparing safety and efficacy between BMMNC and PBMNC as cell-based management in diabetic patients with $\mathrm{PAD}$ who are not suitable for revascularization therapy.

Keywords: Peripheral artery disease, Diabetes mellitus, Stem cell therapy, Bone marrow mononuclear cells, Peripheral blood mononuclear cells

Received: May 21, 2020, Revised: October 18, 2020,

Accepted: October 19, 2020, Published online: December 31, 2020

Correspondence to Em Yunir

Department of Internal Medicine, Dr. Cipto Mangunkusumo National General Hospital, Faculty of Medicine Universitas Indonesia, Jl. Diponegoro No. 71, Jakarta 10430, Indonesia

Tel: +62-21-3907703, Fax: +62-21-3928659

E-mail: e.yunir@ui.ac.id

(c) This is an open-access article distributed under the terms of the Creative Commons Attribution Non-Commercial License (http://creativecommons.org/ licenses/by-nc/4.0/), which permits unrestricted non-commercial use, distribution, and reproduction in any medium, provided the original work is properly cited.

Copyright (c) 2021 by the Korean Society for Stem Cell Research

\section{Introduction}

Peripheral artery disease (PAD) is a part of non-coronary artery syndrome caused by changes in the lower extremities' arterial structure and function, which atherosclerotic lesion and thrombo-embolism are generally considered as the underlying pathophysiology (1). Worldwide, more than 200 million people were affected by this disease in 2010 (2). Many studies have shown a strong association between diabetes mellitus (DM) and an increased prevalence of $\operatorname{PAD}(3,4)$. Indeed, $\mathrm{PAD}$ is an established manifestation of macrovascular complications in diabetes other 
than coronary artery disease and stroke. Approximately $20 \%$ of DM patients older than 40 years were affected by PAD. Meanwhile, $20 \sim 30 \%$ of PAD patients have DM (3). Our data in Dr. Cipto Mangunkusumo National General Hospital, Jakarta, Indonesia, showed that between 2008 and 2012, there were 54 patients with PAD underwent endovascular revascularization and almost $80 \%$ of them had type 2 diabetes (T2D) (5).

As evident, the presence of diabetes greatly accelerates PAD disease progression, with a more severe below-the-knee lesion, and significantly increases the risk of ischemic ulcer, gangrene, and major amputation rates, compared to those without DM (6). Around $10 \sim 20 \%$ of patients with lower limb PAD will progress to critical limb ischemia (CLI), a severe form of PAD characterized by pain at rest, ulceration, and necrosis $(7,8)$. CLI is associated with unfavorable prognosis, recurrent hospitalization, lower quality of life, higher risk for cardiovascular death, and 5-year survival rates of $50 \%$ or even less (9). In addition to optimum medical therapy and risk factors modification, the current gold standard management for severe PAD and CLI is revascularization through endovascular intervention or surgical bypass $(10,11)$. Unfortunately, up to $40 \%$ of these patients were not good candidates for revascularization procedures due to excessive operative risk or unfavorable vascular involvement (12). Therefore, a new approach is in great demand for these 'no option' patients to reduce the amputation and mortality rates. In the past two decades, autologous stem cell therapy, especially mononuclear cells (MNC), has been used extensively for 'no option' CLI patients with promising results. However, it is still not available for routine clinical practice. This review will compare the two primary sources of MNC, peripheral blood and bone marrow (BM), for its use in CLI management in diabetes patients.

\section{Stem Cell Therapy}

Stem cell therapy has emerged as a new therapeutic strategy for many diseases. Stem cells are cells that have the capacity to renew themselves and to produce differentiated cells. Based on the extent to which they can differentiate into different cell types, stem cells can be classified as totipotent, pluripotent, multipotent, oligopotent, or unipotent (13). Additionally, based on their origin, stem cells can be classified into four broad types: embryonic, fetus, infant, and adult stem cells (13, 14). Embryonic stem cells, which have pluripotent properties, can differentiate into any type of cell in the body. Meanwhile, the adult stem cells with multipotent properties pose a higher specificity than embryonic stem cells. They could produce different types of cells only for specific organs and tissues (14). In contrast to embryonic stem cells, the ethical aspects of adult stem cells are relatively not controversial because they originate from tissue samples of adult humans, not human embryos. Although, safety issues especially for long-term follow-up, are still becoming a concern (15).

In normal tissue experiencing an ischemic injury, there will be a revascularization compensatory response consisting of angiogenesis, vasculogenesis, and arteriogenesis that plays an essential role in repairing damaged blood vessels and forming new blood vessels or neovascularization (16). These very intricate processes involved inflammatory cells, numerous chemokines and cytokines, various growth factors, and stem cells (16-18). Unfortunately, these mechanisms are defective in diabetes and CLI patients $(19,20)$. The tremendous potential inherited by stem cells to differentiate and evolve into differentiated cell types holds the prospect to be used as one modality for PAD or CLI management in T2D patients. The stem cells gradually get stimulated by the surrounding cellular environment (damaged hypoxic tissues), which will lead to the formation of specialized cells identical to those they come in contact and grow with $(21,22)$. Paracrine effects induced by the stem cells were also responsible for supporting these reparative processes (23).

\section{Bone Marrow Mononuclear Cells (BMMNC)}

As one primary source of adult stem cells, bone marrow has been explored extensively for its use in stem cell therapy in CLI. Type of stem cells from the bone marrow that has have been widely used as therapy include bone marrow mononuclear cells (BMMNC), or its subsets, which consist of endothelial progenitor cells (EPC) and mesenchymal stem/stromal cells (MSC).

The term BMMNC is used to describe cells with unilobed or round nuclei and lack of granules in the cytoplasm that are found in the bone marrow. This broad definition results in a diverse cell population that comprises hematopoietic stem and progenitor cells (HSC/HPC), lymphoid cells, monocyte, and mesenchymal stem cells (MSCs). These characteristics differ from those of myeloid and red blood cell progenitor, thereby facilitating the separation of BMMNC by physical means (24). Further efforts have been made to characterize the angiogenic stem and progenitor population in the BMMNC fraction. Asahara et al. (22) have managed to identify a class of circulating mononuclear cells expressing CD34 with the ability to differentiate into endothelial cells in vitro and con- 
tribute to vasculogenesis in adult animal models, thus defined as putative EPC. Although, until now, the concept of EPC has become a subject of debate and controversies, as many studies from different research groups have used different isolation methods and identification to define EPC-like cells (25-28). Moreover, many markers that were previously used to describe putative EPC, such as CD34, CD117, and CD133, have also been known to be shared by myeloid cells of various stages of differentiation (29, 30). Thus, make the issues more complicated.

Another imperative fraction of BMMNC is the MSC. Despite their small number in bone marrow $(\sim 1$ in every ten thousand bone marrow cells), these cells can be multiplied ex-vivo into larger quantities to achieve required doses (31). In addition, there are also alternative sources of MSCs, including adipose tissues $(32,33)$, dental pulp (34), periodontal ligament (35) peripheral blood (36), cord blood (37), umbilical cord (38, 39), and placenta (40). International Society for Cell Therapy (ISCT) proposed the minimum criteria to describe multipotent MSCs, which are plastic adherence in ordinary culture conditions; expression of cell surface CD73, CD90, and CD105; lack of expression of cell-surface CD34, CD45, HLA-DR, CD14, CD79a, or CD19; and multilineage differentiation capacity (41). Despite these proposition, it is prominent that MSCs isolated from different tissue and/or under different conditions will likely result in diverse or more differentiated stem cells, albeit still defined as multipotent progenitor cells $(42,43)$. Due to these variations, it should be kept in mind that MSCs between studies are less likely to signify identical cell types since details such as expansion technique and isolation method may affect clinical results.

BMMNC used for therapeutic purposes in clinical trials usually obtained by bone-marrow aspiration from ileum under local or general anesthesia depending on the withdrawn volume $(44,45)$. Next, the aspirate will undergo a purification and concentration step using a density gradient centrifugation, either manually or preferably by an automated cell separator (46). The application of an automated cell separator allowed for shorter processing time and reduced risk of microbial contamination with higher mononuclear cells recovery and preserved or even better functional capacity $(47,48)$.

\section{Peripheral Blood Mononuclear Cells (PBMNC)}

A peripheral blood mononuclear cell (PBMNC) is any peripheral blood cell having a round nucleus, consisting of lymphocytes (T cells, B cells, NK cells) and monocytes
(49). The EPCs could also be identified in isolated PBMNC, although only as a small fraction (50). As the mononuclear cells in the peripheral blood originally come from bone marrow, these cells could be stimulated or mobilized by giving a systemic injection of granulocyte colony-stimulating factor (G-CSF) or granulocyte-macrophage colony-stimulating factor (GM-CSF) to increase the number in the peripheral blood without affecting its function and capacity (51-53). Thus, the quantities or dosage of this CD34+ mobilized PBMNC will be sufficient for therapeutic angiogenesis. The receptors of G-CSF are expressed primarily on neutrophils and bone marrow precursor cells. Whereas, for GM-CSF, the receptors are more widely expressed and present on neutrophils, monocytes, eosinophils, dendritic cells, basophils, and B cells (54). Both growth factors decreased the expression of adhesion molecules on the CD34+ cells, such as very late antigen-1 (VLA-1), L-selectin, vascular cell adhesion molecule-1 (VCAM-1), and CXCR4 - a receptor for stromal-cell derived factor-1 (SDF-1) - thus facilitating the mobilization of these CD34+ cells to peripheral blood (55).

Several trials have shown that G-CSF and GM-CSF administration leads to a dose-dependent increase of EPC in peripheral blood $(56,57)$. In addition, G-CSF is known to augment differentiation of marrow cells into vasculature endothelial cells, resulting in early blood flow recovery in ischemic tissues (58). However, G-CSF is considered preferable than GM-CSF due to the higher yield of CD34+ cells and less or shorter duration of apheresis (59-61). This might explain the scarcity of study using GM-CSF mobilized PBMNC for critical limb ischemia. Important drawbacks of research using stem cell mobilization are their efficacy is significantly influenced by race, ethnics, and disease status (62). Therefore, it is essential to weight patient characteristics when comparing each different PBMNC study. After mobilization with G-CSF or GM-CSF, the PBMNCs are then harvested by means of cell apheresis, either alone or in conjunction with an additional blood-cell separator system (57, 63-65).

\section{Potential Mechanism of BMMNC and PBMNC in PAD}

The mechanism on how BMMNC or PBMNC can promote neovascularization is still considered as an ongoing investigation. A study by Asahara et al. (22) has first demonstrated that peripheral blood CD34 + mononuclear cells can differentiate into endothelial cells and several other studies support this finding (66-68). However, this concept still becomes a controversy since other studies did not ob- 
serve similar result. Studies by Göthert et al. (69) and Purhonen et al. (70) that incorporates fluorescent protein-labeled BM-derived cells failed to discover these cells in the vascular walls after transplantation.

Another proposed mechanism for the role of stem cells in PAD is the stabilization of neovasculature through pericyte differentiation. Pericytes are branched cells that present at intervals along the walls of capillary blood vessels (and postcapillary venules), embedded within the microvascular basement membrane and wrapping endothelial cells (71). Pericytes are communicating with endothelial cells by direct physical contact and paracrine signaling pathways. They play an essential role in stabilizing the vessel wall, regulating microvascular blood flow, and endothelial cell proliferation $(72,73)$. By utilizing green fluorescent protein (GFP)-chimeric mice, Rajantie et al. (74) were unable to find evidence of BM-derived endothelial cells at sites of tumor or vascular endothelial growth factor (VEGF)-induced angiogenesis. Instead, they consistently observed BM-derived periendothelial cells at the sites, and these cells expressed NG2 proteoglycan, a marker for developing pericytes. These findings are supported by Ziegelhoeffer et al. (75), who also used GFP-chimeric mice that underwent unilateral femoral artery occlusions as a model of hind-limb ischemia. They failed to colocalize GFP signals with endothelial or smooth muscle cells marker in the growing collateral arteries. Nevertheless, accumulations of GFP-positive cells were detected in the perivascular space, appearing like pericytes and fibroblasts based on their shape and distribution. These suggest that in the adult organism, BM-derived cells do not promote vascular growth by incorporating into vessel walls but may function as supporting cells.

Besides direct incorporation into the vascular structure, BMMNC might play an essential role in neovascularization in $\mathrm{PAD}$ via its potent paracrine signaling. In the site of vascular injury, BMMNC and PBMNC have been found to secrete various pro-angiogenic factors, such as basic fibroblast growth factor (bFGF), VEGF, hepatocyte growth factor (HGF), and angiopoietin-1 $(76,77)$. VEGF is one of the main regulators in angiogenesis. It acts as a chemotactic marker for macrophage and granulocyte and stimulates endothelial cells migration, matrix metalloproteinase activity, and forming of the blood vessel lumens (78). Additionally, it can also promote vessel enlargement, increase vessel branching, and maintaining vascular homeostasis (79). Meanwhile, bFGF exerts its role in angiogenesis by stimulating endothelial cells migration, invasion, and production of plasminogen activator, as well as influencing other growth factors and chemokines secre- tion $(80,81)$. HGF has similar properties to bFGF and can enhance the angiogenesis potency of VEGF (82). These growth factors have been used in several clinical trials as a therapy for critical limb ischemia, although with mixed results (83).

\section{Clinical Trials of Stem Cell Therapy for PAD in Diabetes Patients}

Animal trials using rabbit, rat, and mouse in hind-limb ischemia (HLI) models have shown promising result in which BMMNC, PBMNC, or MSC transplantation could improve capillary density, neovascularization and collateral growth, blood perfusion, upregulation of b-FGF and VEGF levels, as well as decreases in auto amputation rate and muscle atrophy (84).

These encouraging results from animal studies prompt Tateishi-Yuyama et al. (85) to conduct the Therapeutic Angiogenesis using Cell Transplantation (TACT) study, the earliest human clinical trial using intramuscular injection of autologous BMMNC or unstimulated PBMNC in the ischemic limb of PAD patients with CLI. This pilot study demonstrated significant improvement in ankle-brachial index (ABI), transcutaneous oxygen pressure (TCPO2), resting pain, and pain-free walking time, that persists after 24 weeks in BMMNC compared to the unstimulated PBMNC.

Clinical studies of BMMNC and PBMNC therapy for limb ischemia have significantly improved from uncontrolled phase I trial to ongoing randomized, placebo-controlled, clinical phase III trial. Huang et al. (56) first described the benefit of autologous mobilized PBMNC transplantation in diabetic CLI in terms of lower limb amputation, limb ulcer healing, ischemic pain, blood perfusion, and ABI. This study utilized five days of G-CSF therapy to mobilize the MNCs to peripheral blood, followed by apheresis which was then used for autologous injection. Despite Tateishi-Yuyama et al. (85) demonstrated the superiority of BMMNC compared to unstimulated PBMNC, it is important to note that Tateishi-Yuyama et al. did not mobilize the MNCs using G-CSF. This might result in a very low number of MNCs or CD34+ cells in the PBMNCtreated subjects, thus potentially affecting the outcome. However, a recent study by Persiani et al. (86) utilizing unstimulated PBMNC showed a significant improvement of $\mathrm{ABI}$ and ischemic pain in diabetic CLI patients after transplantation. Ozturk et al. (57) reported better improvement of Fontaine score, ABI, TcPO2, and pain score in diabetic CLI patients treated with G-CSF mobilized PBMNC compared to control subjects treated with stand- 
ard of care. Additionally, a more recent larger-scale randomized clinical trial by Horie et al. (87) using G-CSF mobilized PBMNC transplantation showed that PBMNC therapy was able to significantly improve the progressionfree survival of mild-to-moderate PAD.

Several trials conducted to compare the efficacy between BMMNC and PBMNC as CLI therapy has shown mixed results. A study by Dubsky et al. (65) diabetic CLI patients, showed no differences in the improvement of TcPO2 between BMMNC and PBMNC group, which complied with the finding from Huang et al. (64). However, the latter study reported significantly better improvement in $\mathrm{ABI}$, skin temperature, and resting pain after 12 weeks in PBMNC than BMMNC group. In addition, a metaanalysis by Liew et al. (88) demonstrated a better reduction of major amputation rate, improvement of ulcer healing, and $\mathrm{ABI}$ in PBMNC but not BMMNC when compared to the control group. Therefore, PBMNC might not be inferior to BMMNC, especially with the added practicality of avoiding invasive and painful procedure, its adverse risk, and cost. In the future, PBMNC treatment can even be commenced as an outpatient procedure to reduce patient burden.

There has been a significant number of meta-analysis assessing the effect of stem cells therapy in PAD. Mostly, these meta-analyses demonstrated a substantial improvement of surrogate endpoints such as ABI, TcPO2, ischemic pain, ulcer healing, and pain-free walking distance (PFWD) after stem cells transplantation. However, in terms of primary outcomes such as amputation rate, overall survival or mortality, and amputation-free survival (AFS), mixed results have been observed (89-93). Ai et al. (90) and Rigato et al. (91) showed a reduced major amputation rate and an increased rate of AFS in cell-based therapy. Xie et al. (92) and Gao et al. (94) also revealed a reduction in total amputation rate after stem cell therapy but failed to show improvement in major limb salvage. Meanwhile, meta-analyses that only include trials with randomized placebo-controlled intervention or with low risk of bias consistently did not show a significant improvement in total or major amputation rate, mortality, and AFS in the treatment group compared to placebo, after stem-cells transplantation $(88,93,95)$.

It appears that the earlier relatively small and non-placebo controlled trials demonstrated more evident advantages of cell therapy, whereas the larger placebo-controlled studies showed less convincing results. It is important to note that there is a high risk of bias in the type of trials without randomization and placebo-controlled, whether in the intervention given or outcome evaluation. Many clin- ical trials have failed to show the advantages of stem cell therapy for PAD in the major amputation rate and overall survival. We could speculate that the improvement of neovascularization as shown by the improved surrogate outcome is not sufficient to the extent of preventing major amputation. Moreover, diabetic patients with CLI might already have many complications in the other organs and the possibility of diffuse atherosclerotic lesions in the other vascular beds, including cardiovascular and cerebrovascular system (6). These conditions will eventually increase the risk of mortality, which cannot be corrected by merely administering stem cell therapy.

\section{Pitfalls of Stem Cell Therapy for PAD in Diabetes}

Preclinical studies initially raise some concerns regarding the efficacy of autologous MNC in diabetic individuals. Hyperglycemia condition in diabetes is associated with decreased number and function of EPC. Animal studies have shown that diabetic EPCs exhibit decreases adhesion and migration activities; decreased fibronectin, collagen I, vitronectin, and laminin expression; impaired expression of eNOS and VEGF; and reduced capability to incorporate into the vascular structure (19, 96). Many studies have revealed a significantly decreased number of circulating CD34+ cells in diabetic patients, especially with foot ulcers and PAD (97-99). Additionally, this reduced quantity of circulating EPC is more prevalent in complicated diabetes rather than uncomplicated diabetes (96). Despite all these drawbacks, treatment of autologous mobilized PBMNC could still improve neovascularization, albeit to a lesser extent than nondiabetics (100). Interestingly, a recent meta-regression analysis by Rigato et al. (91) and meta-analysis by Gao et al. (94) implied that the benefit of cell therapy on amputation rate was higher in trials with a majority of patients having diabetes mellitus.

With regards to optimization studies, discussion about optimal dose and delivery route remains open. A metaanalysis by $\mathrm{Ai}$ et al. (90) did not find a significant correlation between cell dosages and the therapeutic effects. Additionally, a study by Losordo et al. (101) showed the lowest beneficial dose for CD34+ cells for PAD is $1 \times 10^{5}$ cells/kg body weight and increasing the number of injected cells would not result in significant improvement of the outcomes. However, a meta-analysis by Pan et al. (93) showed significant results in major amputation, total amputation, and complete ulcer healing rate in the high CD $34+$ cell dosage $\left(1 \times 10^{6}\right.$ cells/kg body weight), which were not observed in low-dose studies. Hence, more studies comparing different cell dosages with a sufficient num- 
ber of subjects and randomized placebo-controlled designs are needed to confirm the optimal dosage for MNC therapy in PAD.

The intramuscular approach injects a high concentration of stem cells in the ischemic areas that require angiogenesis. Despite documented low engraftment rate (0.44 - 10\% after 96 hours) (84), the justification behind intramuscular injection is to deposit cell reservoir near the ischemic area (Fig. 1). On the other hand, the intraarterial method aims to direct stem cells to margin areas with adequate supply of oxygen and nutrients to promote new cell activities. However, it is not yet known how many cells able to reach the ischemic areas from the blood vessels. Studies that directly compare intramuscular and intraarterial injection of BMMNC in CLI patients have shown no significant differences (102, 103).

The safety of BMMNC and PBMNC therapy for PAD has generally been established. Although bone marrow as- piration as a procedure to obtain the BMMNC is considered more invasive compared to apheresis for obtaining PBMNC, it is still categorized as low-risk procedure. Some potential adverse events associated with bone marrow aspiration include pain, low-grade fever, bleeding, and infection (104). In addition, bone marrow aspiration, especially with large volume aspirate, has also been described to decrease mean hematocrit by $2.6 \%$ compared to control. However, this condition is tolerable in most patients (102). Nevertheless, this should be considered in at-risk patients such as anemic or coronary artery disease patients. Meanwhile, the administration of G-CSF for mobilization of PBMNC before apheresis carries some potential risks. Mostly, the adverse events are mild such as bone pain, headache, fatigue, and flu-like symptoms (105). However, there are some case reports on very rare cases of serious adverse events associated with G-CSF injection in healthy subjects, like spleen rupture (106), acute lung injury (107),

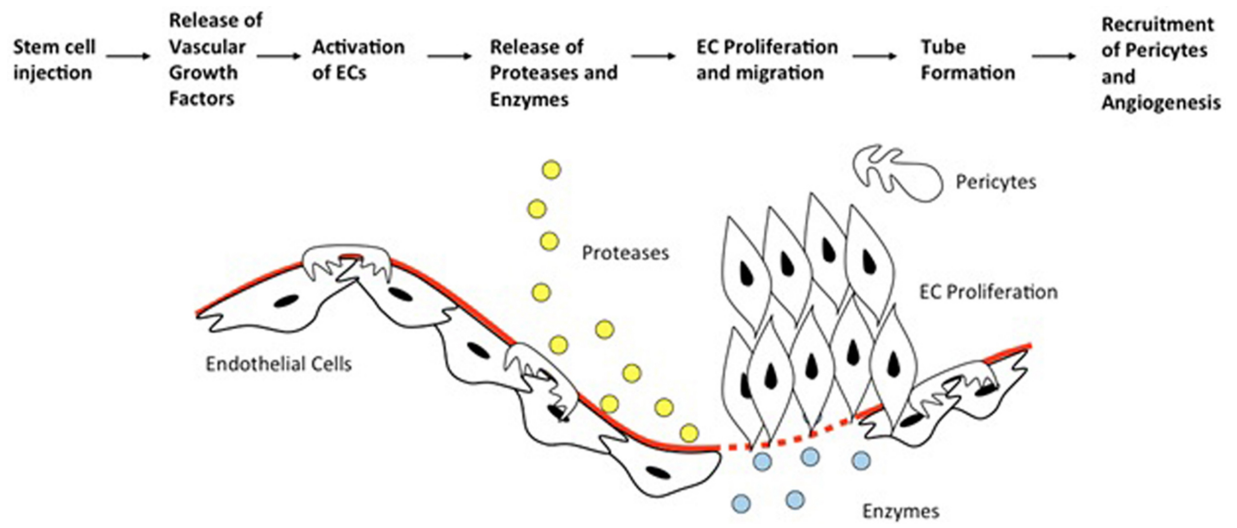

Fig. 1. A schematic diagram of angiogenesis process following stem cell injection of the affected area of PAD. EC: Endothelial Cells. Adapted from: Lawall $\mathrm{H}$, et al. Thromb Haemost; 2010.

Table 1. Advantages and drawbacks of cell products used for peripheral artery disease

\begin{tabular}{|c|c|c|}
\hline Cell therapy types & Advantages & Drawbacks \\
\hline $\begin{array}{l}\text { Bone-Marrow derived } \\
\text { Mononuclear Cells } \\
\text { (BMMNC) }\end{array}$ & $\begin{array}{l}\text { - Most widely researched cell product for PAD. } \\
\text { - Several meta-analyses showed improvement in ABI, TcPO2, pain } \\
\text { scores, and ulcer healing in BMMNC treated patients (90-92). } \\
\text { - Availability of long term safety result (3 years) (109). }\end{array}$ & $\begin{array}{l}\text { Risk and complications during bone } \\
\text { marrow aspiration. }\end{array}$ \\
\hline $\begin{array}{l}\text { Peripheral Blood } \\
\text { derived } \\
\text { Mononuclear Cells } \\
\text { (PBMNC) }\end{array}$ & $\begin{array}{l}\text { - Head-to-head comparison with BMMNC showed similar benefits (65). } \\
\text { - Recent meta-analysis showed PBMNC, but not BMMNC are able to } \\
\text { reduce risk of major amputation and improve ulcer healing (88). } \\
\text { - Availability of long term safety result (1 year) (101). }\end{array}$ & $\begin{array}{l}\text { - Risk and complications during } \\
\text { G-CSF/GM-CSF administration (105). } \\
\text { - Efficacy of stem cells mobilizations are } \\
\text { significantly influenced by race, } \\
\text { ethnics, and disease status (62). }\end{array}$ \\
\hline $\begin{array}{l}\text { Mesenchymal Stem } \\
\text { Cells (MSC) }\end{array}$ & $\begin{array}{l}\text { - Promising result from preclinical and clinical studies. } \\
\text { - Able to be isolated and expanded to achieve consistentand desirable } \\
\text { dose. } \\
\text { - Allow larger-scale manufacturing with good quality control to } \\
\text { produce an 'off the-shelf' cellular products. } \\
\text { - Possibility of allogeneic therapy due to its non or low-antigenic } \\
\text { properties. }\end{array}$ & $\begin{array}{l}\text { - Risk and complications during bone } \\
\text { marrow aspiration (in BMMSC). } \\
\text { - Reports of potential role of MSC in } \\
\text { tumor development. } \\
\text { - High variability of cell products } \\
\text { between protocols and research facility. } \\
\text { - Relatively more expensive. }\end{array}$ \\
\hline
\end{tabular}


and transient state of hypercoagulability that could give rise to thrombotic complications (108). No muscular damage, blood vessel malformation, or acute kidney injury has been identified with any intramuscular injection of MNCs (88). Additionally, there is also no report of unexpected long-term adverse effects $(109,110)$. The advantages and drawbacks of cell products used for PAD are shown in Table 1 .

\section{Conclusions}

Extensive phase I and II trials have established the safety of BMMNC and PBMNC as well as its efficacy in improving ischemic pain, reducing ulcer size, pain-free walking distance, ABI, and TcPO2. Nonetheless, the capacity to establish the efficacy to reduce major amputation rates, AFS, and all-cause mortality is still lacking due to the limited number of phase III studies. In addition, an occurring trend is observed in which small, non-placebo-controlled study seems to demonstrate a seemingly larger benefit compared to large, placebo-controlled study. This phenomenon raises some concern, especially because several important endpoints are susceptible to bias. Future larger placebo-controlled RCTs are needed before further translation of MNC therapy to standard care. Additionally, current clinical trials using MNC therapy in PAD are only performed in end-stage disease PAD when the patients are unable to undergo revascularization treatment. It might be important to conduct clinical study in mild to moderate PAD to not miss the potential benefit of this novel therapy as the more advanced disease is related to the decreased regenerative capabilities of the vasculature and the functionality of the autologous stem cells itself.

\section{Acknowledgments}

The authors thank to Yully Astika Nugrahayning Aziza and Eni Iswati for their help in preparing the manuscript.

\section{Potential Conflict of Interest}

The authors have no conflicting financial interest.

\section{References}

1. Hirsch AT, Haskal ZJ, Hertzer NR, Bakal CW, Creager MA, Halperin JL, Hiratzka LF, Murphy WR, Olin JW, Puschett JB, Rosenfield KA, Sacks D, Stanley JC, Taylor LM Jr, White CJ, White J, White RA, Antman EM, Smith SC Jr, Adams CD, Anderson JL, Faxon DP, Fuster V, Gibbons RJ, Halperin JL, Hiratzka LF, Hunt SA, Jacobs AK, Nishimura R, Ornato JP, Page RL, Riegel B.
ACC/AHA 2005 guidelines for the management of patients with peripheral arterial disease (lower extremity, renal, mesenteric, and abdominal aortic): executive summary a collaborative report from the American Association for Vascular Surgery/Society for Vascular Surgery, Society for Cardiovascular Angiography and Interventions, Society for Vascular Medicine and Biology, Society of Interventional Radiology, and the ACC/AHA Task Force on Practice Guidelines (Writing Committee to Develop Guidelines for the Management of Patients With Peripheral Arterial Disease) endorsed by the American Association of Cardiovascular and Pulmonary Rehabilitation; National Heart, Lung, and Blood Institute; Society for Vascular Nursing; TransAtlantic Inter-Society Consensus; and Vascular Disease Foundation. J Am Coll Cardiol 2006;47: 1239-1312

2. Fowkes FG, Rudan D, Rudan I, Aboyans V, Denenberg JO, McDermott MM, Norman PE, Sampson UK, Williams LJ, Mensah GA, Criqui MH. Comparison of global estimates of prevalence and risk factors for peripheral artery disease in 2000 and 2010: a systematic review and analysis. Lancet 2013;382:1329-1340

3. Marso SP, Hiatt WR. Peripheral arterial disease in patients with diabetes. J Am Coll Cardiol 2006;47:921-929

4. Kamil S, Sehested TSG, Carlson N, Houlind K, Lassen JF, N Bang C, Dominguez H, Pedersen CT, Gislason GH. Diabetes and risk of peripheral artery disease in patients undergoing first-time coronary angiography between 2000 and 2012- a nationwide study. BMC Cardiovasc Disord 2019;19:234

5. Maulahela H. Clinical outcome of percutaneus transluminal angioplasty in type 2 diabetic patient with peripheral arterial disease and distribution of factors that influenced clinical success [thesis]. Depok: Universitas Indonesia; 2013.

6. Thiruvoipati T, Kielhorn CE, Armstrong EJ. Peripheral artery disease in patients with diabetes: epidemiology, mechanisms, and outcomes. World J Diabetes 2015;6:961969

7. Nehler MR, Duval S, Diao L, Annex BH, Hiatt WR, Rogers K, Zakharyan A, Hirsch AT. Epidemiology of peripheral arterial disease and critical limb ischemia in an insured national population. J Vasc Surg 2014;60:686-695. e2

8. Sigvant B, Lundin F, Wahlberg E. The risk of disease progression in peripheral arterial disease is higher than expected: a meta-analysis of mortality and disease progression in peripheral arterial disease. Eur J Vasc Endovasc Surg 2016;51:395-403

9. Duff S, Mafilios MS, Bhounsule P, Hasegawa JT. The burden of critical limb ischemia: a review of recent literature. Vasc Health Risk Manag 2019;15:187-208

10. Mills JL. Lower limb ischaemia in patients with diabetic foot ulcers and gangrene: recognition, anatomic patterns and revascularization strategies. Diabetes Metab Res Rev 2016;32 Suppl 1:239-245 
11. Gerhard-Herman MD, Gornik HL, Barrett C, Barshes NR, Corriere MA, Drachman DE, Fleisher LA, Fowkes FG, Hamburg NM, Kinlay S, Lookstein R, Misra S, Mureebe L, Olin JW, Patel RA, Regensteiner JG, Schanzer A, Shishehbor MH, Stewart KJ, Treat-Jacobson D, Walsh ME. 2016 AHA/ACC guideline on the management of patients with lower extremity peripheral artery disease: executive summary: a report of the American college of cardiology/American Heart Association task force on clinical practice guidelines. Circulation 2017;135:e686-e725

12. Adam DJ, Beard JD, Cleveland T, Bell J, Bradbury AW, Forbes JF, Fowkes FG, Gillepsie I, Ruckley CV, Raab G, Storkey H. Bypass versus angioplasty in severe ischaemia of the leg (BASIL): multicentre, randomised controlled trial. Lancet 2005;366:1925-1934

13. Kalra K, Tomar PC. Stem cell: basics, classification and applications. Am J Phytomed Clin Ther 2014;2:919-930

14. Barky AR, Ali EMM, Mohamed TM. Stem cells, classifications and their clinical applications. Am J Pharmacol Ther 2017;1:1-7

15. Volarevic V, Markovic BS, Gazdic M, Volarevic A, Jovicic $\mathrm{N}$, Arsenijevic N, Armstrong L, Djonov V, Lako M, Stojkovic M. Ethical and safety issues of stem cell-based therapy. Int J Med Sci 2018;15:36-45

16. Silvestre JS, Mallat Z, Tedgui A, Lévy BI. Post-ischaemic neovascularization and inflammation. Cardiovasc Res 2008;78:242-249

17. Tuomisto TT, Rissanen TT, Vajanto I, Korkeela A, Rutanen J, Ylä-Herttuala S. HIF-VEGF-VEGFR-2, TNFalpha and IGF pathways are upregulated in critical human skeletal muscle ischemia as studied with DNA array. Atherosclerosis 2004;174:111-120

18. Urbich C, Dimmeler S. Endothelial progenitor cells: characterization and role in vascular biology. Circ Res 2004;95: 343-353

19. Kolluru GK, Bir SC, Kevil CG. Endothelial dysfunction and diabetes: effects on angiogenesis, vascular remodeling, and wound healing. Int J Vasc Med 2012;2012:918267

20. Mendoza MG, Robles HV, Romo E, Rios A, Escalante B. Nitric oxide-dependent neovascularization role in the lower extremity disease. Curr Pharm Des 2007;13:3591-3596

21. Santarelli JG, Udani V, Yung YC, Cheshier S, Wagers A, Brekken RA, Weissman I, Tse V. Incorporation of bone marrow-derived Flk-1-expressing CD $34^{+}$cells in the endothelium of tumor vessels in the mouse brain. Neurosurgery 2006;59:374-382; discussion 374-382

22. Asahara T, Murohara T, Sullivan A, Silver M, van der Zee $\mathrm{R}, \mathrm{Li} \mathrm{T}$, Witzenbichler B, Schatteman G, Isner JM. Isolation of putative progenitor endothelial cells for angiogenesis. Science 1997;275:964-967

23. Gnecchi M, Zhang Z, Ni A, Dzau VJ. Paracrine mechanisms in adult stem cell signaling and therapy. Circ Res 2008;103:1204-1219

24. Xie J, March KL, Murphy MP. Bone marrow- derived cells: From the laboratory to the clinic. In: Mohler ER, Annex BH, editor. Regenerative Medicine for Peripheral
Artery Disease. San Diego: Elsevier Inc.; 2016. 27-42

25. Hill JM, Zalos G, Halcox JP, Schenke WH, Waclawiw MA, Quyyumi AA, Finkel T. Circulating endothelial progenitor cells, vascular function, and cardiovascular risk. N Engl J Med 2003;348:593-600

26. Bompais H, Chagraoui J, Canron X, Crisan M, Liu XH, Anjo A, Tolla-Le Port C, Leboeuf M, Charbord P, Bikfalvi A, Uzan G. Human endothelial cells derived from circulating progenitors display specific functional properties compared with mature vessel wall endothelial cells. Blood 2004;103:2577-2584

27. Romagnani P, Annunziato F, Liotta F, Lazzeri E, Mazzinghi B, Frosali F, Cosmi L, Maggi L, Lasagni L, Scheffold A, Kruger M, Dimmeler S, Marra F, Gensini G, Maggi E, Romagnani S. CD14 ${ }^{+}$CD34low cells with stem cell phenotypic and functional features are the major source of circulating endothelial progenitors. Circ Res 2005;97:314-322

28. Ingram DA, Mead LE, Tanaka H, Meade V, Fenoglio A, Mortell K, Pollok K, Ferkowicz MJ, Gilley D, Yoder MC. Identification of a novel hierarchy of endothelial progenitor cells using human peripheral and umbilical cord blood. Blood 2004;104:2752-2760

29. Fadini GP, Losordo D, Dimmeler S. Critical reevaluation of endothelial progenitor cell phenotypes for therapeutic and diagnostic use. Circ Res 2012;110:624-637

30. Yoder MC. Endothelial progenitor cell: a blood cell by many other names may serve similar functions. J Mol Med (Berl) 2013;91:285-295

31. Thirumala S, Goebel WS, Woods EJ. Manufacturing and banking of mesenchymal stem cells. Expert Opin Biol Ther 2013;13:673-691

32. Nakagami H, Maeda K, Morishita R, Iguchi S, Nishikawa T, Takami Y, Kikuchi Y, Saito Y, Tamai K, Ogihara T, Kaneda Y. Novel autologous cell therapy in ischemic limb disease through growth factor secretion by cultured adipose tissue-derived stromal cells. Arterioscler Thromb Vasc Biol 2005;25:2542-2547

33. Iwashima S, Ozaki T, Maruyama S, Saka Y, Kobori M, Omae K, Yamaguchi H, Niimi T, Toriyama K, Kamei Y, Torii S, Murohara T, Yuzawa Y, Kitagawa Y, Matsuo S. Novel culture system of mesenchymal stromal cells from human subcutaneous adipose tissue. Stem Cells Dev 2009; $18: 533-543$

34. Gronthos S, Mankani M, Brahim J, Robey PG, Shi S. Postnatal human dental pulp stem cells (DPSCs) in vitro and in vivo. Proc Natl Acad Sci U S A 2000;97:1362513630

35. Tomokiyo A, Yoshida S, Hamano S, Hasegawa D, Sugii $\mathrm{H}$, Maeda H. Detection, characterization, and clinical application of mesenchymal stem cells in periodontal ligament tissue. Stem Cells Int 2018;2018:5450768

36. Ukai R, Honmou O, Harada K, Houkin K, Hamada H, Kocsis JD. Mesenchymal stem cells derived from peripheral blood protects against ischemia. J Neurotrauma 2007; 24:508-520 
37. Kim SW, Han H, Chae GT, Lee SH, Bo S, Yoon JH, Lee YS, Lee KS, Park HK, Kang KS. Successful stem cell therapy using umbilical cord blood-derived multipotent stem cells for Buerger's disease and ischemic limb disease animal model. Stem Cells 2006;24:1620-1626

38. Romanov YA, Svintsitskaya VA, Smirnov VN. Searching for alternative sources of postnatal human mesenchymal stem cells: candidate MSC-like cells from umbilical cord. Stem Cells 2003;21:105-110

39. Xu Y, Meng H, Li C, Hao M, Wang Y, Yu Z, Li Q, Han J, Zhai Q, Qiu L. Umbilical cord-derived mesenchymal stem cells isolated by a novel explantation technique can differentiate into functional endothelial cells and promote revascularization. Stem Cells Dev 2010;19:1511-1522

40. Oliveira MS, Barreto-Filho JB. Placental-derived stem cells: culture, differentiation and challenges. World J Stem Cells 2015;7:769-775

41. Dominici M, Le Blanc K, Mueller I, Slaper-Cortenbach I, Marini F, Krause D, Deans R, Keating A, Prockop Dj, Horwitz E. Minimal criteria for defining multipotent mesenchymal stromal cells. The International Society for Cellular Therapy position statement. Cytotherapy 2006;8: 315-317

42. Petrini M, Pacini S, Trombi L, Fazzi R, Montali M, Ikehara S, Abraham NG. Identification and purification of mesodermal progenitor cells from human adult bone marrow. Stem Cells Dev 2009;18:857-866

43. D'Ippolito G, Diabira S, Howard GA, Menei P, Roos BA, Schiller PC. Marrow-isolated adult multilineage inducible (MIAMI) cells, a unique population of postnatal young and old human cells with extensive expansion and differentiation potential. J Cell Sci 2004;117(Pt 14):2971-2981

44. Subrammaniyan R, Amalorpavanathan J, Shankar R, Rajkumar M, Baskar S, Manjunath SR, Senthilkumar R, Murugan P, Srinivasan VR, Abraham S. Application of autologous bone marrow mononuclear cells in six patients with advanced chronic critical limb ischemia as a result of diabetes: our experience. Cytotherapy 2011;13:993-999

45. Ponemone V, Gupta S, Sethi D, Suthar M, Sharma M, Powell RJ, Harris KL, Jungla N, Arambam P, Kaul U, Seth A, Bukhari S. Safety and effectiveness of bone marrow cell concentrate in the treatment of chronic critical limb ischemia utilizing a rapid point-of-care system. Stem Cells Int 2017;2017:4137626

46. Baker PK, Rhodes EG, Duguid JK. Effective concentration of bone marrow mononuclear cells using density gradient separation within an automated cell separator. Transfus Sci 1992;13:353-356

47. Aktas M, Radke TF, Strauer BE, Wernet P, Kogler G. Separation of adult bone marrow mononuclear cells using the automated closed separation system Sepax. Cytotherapy 2008;10:203-211

48. Hermann PC, Huber SL, Herrler T, von Hesler C, Andrassy J, Kevy SV, Jacobson MS, Heeschen C. Concentration of bone marrow total nucleated cells by a point-of-care device provides a high yield and preserves their functional activity. Cell Transplant 2008;16:10591069

49. Autissier P, Soulas C, Burdo TH, Williams KC. Evaluation of a 12-color flow cytometry panel to study lymphocyte, monocyte, and dendritic cell subsets in humans. Cytometry A 2010;77:410-419

50. Bogoslovsky T, Wang D, Maric D, Scattergood-Keepper L, Spatz M, Auh S, Hallenbeck J. Cryopreservation and enumeration of human endothelial progenitor and endothelial cells for clinical trials. J Blood Disord Transfus 2013;4:158

51. Takahashi T, Kalka C, Masuda H, Chen D, Silver M, Kearney M, Magner M, Isner JM, Asahara T. Ischemiaand cytokine-induced mobilization of bone marrow-derived endothelial progenitor cells for neovascularization. Nat Med 1999;5:434-438

52. Shepherd RM, Capoccia BJ, Devine SM, Dipersio J, Trinkaus KM, Ingram D, Link DC. Angiogenic cells can be rapidly mobilized and efficiently harvested from the blood following treatment with AMD3100. Blood 2006;108: 3662-3667

53. Honold J, Lehmann R, Heeschen C, Walter DH, Assmus B, Sasaki K, Martin H, Haendeler J, Zeiher AM, Dimmeler S. Effects of granulocyte colony simulating factor on functional activities of endothelial progenitor cells in patients with chronic ischemic heart disease. Arterioscler Thromb Vasc Biol 2006;26:2238-2243

54. Bhattacharya P, Thiruppathi M, Elshabrawy HA, Alharshawi K, Kumar P, Prabhakar BS. GM-CSF: an immune modulatory cytokine that can suppress autoimmunity. Cytokine 2015;75:261-271

55. Gazitt Y. Immunologic profiles of effector cells and peripheral blood stem cells mobilized with different hematopoietic growth factors. Stem Cells 2000;18:390-398

56. Huang $\mathrm{P}$, Li S, Han $M$, Xiao Z, Yang R, Han ZC. Autologous transplantation of granulocyte colony-stimulating factor-mobilized peripheral blood mononuclear cells improves critical limb ischemia in diabetes. Diabetes Care 2005;28:2155-2160

57. Ozturk A, Kucukardali Y, Tangi F, Erikci A, Uzun G, Bashekim C, Sen H, Terekeci H, Narin Y, Ozyurt $M$, Ozkan S, Sayan O, Rodop O, Nalbant S, Sildıroglu O, Yalnız FF, Senkal IV, Sabuncu H, Oktenli C. Therapeutical potential of autologous peripheral blood mononuclear cell transplantation in patients with type 2 diabetic critical limb ischemia. J Diabetes Complications 2012;26:29-33

58. Minamino $\mathrm{K}$, Adachi $\mathrm{Y}$, Okigaki $\mathrm{M}$, Ito $\mathrm{H}$, Togawa $\mathrm{Y}$, Fujita K, Tomita M, Suzuki Y, Zhang Y, Iwasaki M, Nakano K, Koike Y, Matsubara H, Iwasaka T, Matsumura $\mathrm{M}$, Ikehara S. Macrophage colony-stimulating factor (M$\mathrm{CSF}$ ), as well as granulocyte colony-stimulating factor (GCSF), accelerates neovascularization. Stem Cells 2005;23: 347-354

59. Lane TA, Law P, Maruyama M, Young D, Burgess J, Mullen M, Mealiffe M, Terstappen LW, Hardwick A, Moubayed M, Oldham F, Corringham RET, Ho AD. Harvesting and enrichment of hematopoietic progenitor cells mobilized into 
the peripheral blood of normal donors by granulocyte-macrophage colony-stimulating factor (GM-CSF) or G-CSF: potential role in allogeneic marrow transplantation. Blood 1995;85:275-282

60. Fischmeister G, Kurz M, Haas OA, Micksche M, Buchinger P, Printz D, Ressmann G, Stroebel T, Peters C, Fritsch G, Gadner H. G-CSF versus GM-CSF for stimulation of peripheral blood progenitor cells (PBPC) and leukocytes in healthy volunteers: comparison of efficacy and tolerability. Ann Hematol 1999;78:117-123

61. Duong HK, Savani BN, Copelan E, Devine S, Costa LJ, Wingard JR, Shaughnessy P, Majhail N, Perales MA, Cutler CS, Bensinger W, Litzow MR, Mohty M, Champlin RE, Leather H, Giralt S, Carpenter PA. Peripheral blood progenitor cell mobilization for autologous and allogeneic hematopoietic cell transplantation: guidelines from the American Society for Blood and Marrow Transplantation. Biol Blood Marrow Transplant 2014;20:1262-1273

62. Hsu JW, Wingard JR, Logan BR, Chitphakdithai P, Akpek G, Anderlini P, Artz AS, Bredeson C, Goldstein S, Hale G, Hematti P, Joshi S, Kamble RT, Lazarus HM, O'Donnell PV, Pulsipher MA, Savani BN, Schears RM, Shaw BE, Confer DL. Race and ethnicity influences collection of granulocyte colony-stimulating factor-mobilized peripheral blood progenitor cells from unrelated donors, a Center for International Blood and Marrow Transplant Research analysis. Biol Blood Marrow Transplant 2015;21: 165-171

63. Poole J, Mavromatis K, Binongo JN, Khan A, Li Q, Khayata M, Rocco E, Topel M, Zhang X, Brown C, Corriere MA, Murrow J, Sher S, Clement S, Ashraf K, Rashed A, Kabbany T, Neuman R, Morris A, Ali A, Hayek S, Oshinski J, Yoon YS, Waller EK, Quyyumi AA. Effect of progenitor cell mobilization with granulocyte-macrophage colony-stimulating factor in patients with peripheral artery disease: a randomized clinical trial. JAMA 2013;310:2631-2639

64. Huang PP, Yang XF, Li SZ, Wen JC, Zhang Y, Han ZC. Randomised comparison of G-CSF-mobilized peripheral blood mononuclear cells versus bone marrow-mononuclear cells for the treatment of patients with lower limb arteriosclerosis obliterans. Thromb Haemost 2007;98:1335-1342

65. Dubsky M, Jirkovska A, Bem R, Fejfarova V, Pagacova L, Sixta B, Varga M, Langkramer S, Sykova E, Jude EB. Both autologous bone marrow mononuclear cell and peripheral blood progenitor cell therapies similarly improve ischaemia in patients with diabetic foot in comparison with control treatment. Diabetes Metab Res Rev 2013;29:369-376

66. Hess DC, Hill WD, Martin-Studdard A, Carroll J, Brailer $\mathrm{J}$, Carothers J. Bone marrow as a source of endothelial cells and NeuN-expressing cells after stroke. Stroke 2002; 33:1362-1368

67. Werner N, Priller J, Laufs U, Endres M, Böhm M, Dirnagl U, Nickenig G. Bone marrow-derived progenitor cells modulate vascular reendothelialization and neointimal formation: effect of 3-hydroxy-3-methylglutaryl coenzyme a reductase inhibition. Arterioscler Thromb Vasc Biol 2002;22:1567-1572

68. Reddy K, Zhou Z, Schadler K, Jia SF, Kleinerman ES. Bone marrow subsets differentiate into endothelial cells and pericytes contributing to Ewing's tumor vessels. Mol Cancer Res 2008;6:929-936

69. Göthert JR, Gustin SE, van Eekelen JA, Schmidt U, Hall MA, Jane SM, Green AR, Göttgens B, Izon DJ, Begley CG. Genetically tagging endothelial cells in vivo: bone marrow-derived cells do not contribute to tumor endothelium. Blood 2004;104:1769-1777

70. Purhonen S, Palm J, Rossi D, Kaskenpää N, Rajantie I, Ylä-Herttuala S, Alitalo K, Weissman IL, Salven P. Bone marrow-derived circulating endothelial precursors do not contribute to vascular endothelium and are not needed for tumor growth. Proc Natl Acad Sci U S A 2008;105:66206625

71. Attwell D, Mishra A, Hall CN, O'Farrell FM, Dalkara T. What is a pericyte? J Cereb Blood Flow Metab 2016;36: 451-455

72. Bergers G, Song S. The role of pericytes in blood-vessel formation and maintenance. Neuro Oncol 2005;7:452-464

73. Caporarello N, D'Angeli F, Cambria MT, Candido S, Giallongo C, Salmeri M, Lombardo C, Longo A, Giurdanella G, Anfuso CD, Lupo G. Pericytes in microvessels: from "mural" function to brain and retina regeneration. Int J Mol Sci 2019;20:6351

74. Rajantie I, Ilmonen M, Alminaite A, Ozerdem U, Alitalo K, Salven P. Adult bone marrow-derived cells recruited during angiogenesis comprise precursors for periendothelial vascular mural cells. Blood 2004;104:2084-2086

75. Ziegelhoeffer T, Fernandez B, Kostin S, Heil M, Voswinckel R, Helisch A, Schaper W. Bone marrow-derived cells do not incorporate into the adult growing vasculature. Circ Res 2004;94:230-238

76. Kamihata H, Matsubara H, Nishiue T, Fujiyama S, Tsutsumi Y, Ozono R, Masaki H, Mori Y, Iba O, Tateishi E, Kosaki A, Shintani S, Murohara T, Imaizumi T, Iwasaka $\mathrm{T}$. Implantation of bone marrow mononuclear cells into ischemic myocardium enhances collateral perfusion and regional function via side supply of angioblasts, angiogenic ligands, and cytokines. Circulation 2001;104: 1046-1052

77. Rehman J, Li J, Orschell CM, March KL. Peripheral blood "endothelial progenitor cells" are derived from monocyte/macrophages and secrete angiogenic growth factors. Circulation 2003;107:1164-1169

78. Dokun AO, Annex BH. The VEGF165b "ICE-o-form" puts a chill on the VEGF story. Circ Res 2011;109:246-247

79. Carmeliet P, Jain RK. Molecular mechanisms and clinical applications of angiogenesis. Nature 2011;473:298-307

80. Montesano R, Vassalli JD, Baird A, Guillemin R, Orci L. Basic fibroblast growth factor induces angiogenesis in vitro. Proc Natl Acad Sci U S A 1986;83:7297-7301

81. Murakami M, Simons M. Fibroblast growth factor regulation of neovascularization. Curr Opin Hematol 2008;15: 
215-220

82. Xin X, Yang S, Ingle G, Zlot C, Rangell L, Kowalski J, Schwall R, Ferrara N, Gerritsen ME. Hepatocyte growth factor enhances vascular endothelial growth factor-induced angiogenesis in vitro and in vivo. Am J Pathol 2001; 158:1111-1120

83. Sanada F, Taniyama Y, Azuma J, Yuka II, Kanbara Y, Iwabayashi M, Rakugi H, Morishita R. Therapeutic angiogenesis by gene therapy for critical limb ischemia: choice of biological agent. Immunol Endocr Metab Agents Med Chem 2014;14:32-39

84. Lawall H, Bramlage P, Amann B. Stem cell and progenitor cell therapy in peripheral artery disease. A critical appraisal. Thromb Haemost 2010;103:696-709

85. Tateishi-Yuyama E, Matsubara H, Murohara T, Ikeda U, Shintani S, Masaki H, Amano K, Kishimoto Y, Yoshimoto K, Akashi H, Shimada K, Iwasaka T, Imaizumi T. Therapeutic angiogenesis for patients with limb ischaemia by autologous transplantation of bone-marrow cells: a pilot study and a randomised controlled trial. Lancet 2002; 360:427-435

86. Persiani F, Paolini A, Camilli D, Mascellari L, Platone A, Magenta A, Furgiuele S. Peripheral blood mononuclear cells therapy for treatment of lower limb ischemia in diabetic patients: a single-center experience. Ann Vasc Surg 2018;53:190-196

87. Horie T, Yamazaki S, Hanada S, Kobayashi S, Tsukamoto T, Haruna T, Sakaguchi K, Sakai K, Obara H, Morishita K, Saigo K, Shintani Y, Kubo K, Hoshino J, Oda T, Kaneko E, Nishikido M, Ioji T, Kaneda H, Fukushima M. Outcome from a randomized controlled clinical trial- improvement of peripheral arterial disease by granulocyte colony-stimulating factor-mobilized autologous peripheral-blood-mononuclear cell transplantation (IMPACT). Circ J 2018;82:2165-2174

88. Liew A, Bhattacharya V, Shaw J, Stansby G. Cell therapy for critical limb ischemia: a meta-analysis of randomized controlled trials. Angiology 2016;67:444-455

89. Wen Y, Meng L, Gao Q. Autologous bone marrow cell therapy for patients with peripheral arterial disease: a meta-analysis of randomized controlled trials. Expert Opin Biol Ther 2011;11:1581-1589

90. Ai M, Yan CF, Xia FC, Zhou SL, He J, Li CP. Safety and efficacy of cell-based therapy on critical limb ischemia: a meta-analysis. Cytotherapy 2016;18:712-724

91. Rigato M, Monami M, Fadini GP. Autologous cell therapy for peripheral arterial disease: systematic review and meta-analysis of randomized, nonrandomized, and noncontrolled studies. Circ Res 2017;120:1326-1340

92. Xie B, Luo H, Zhang Y, Wang Q, Zhou C, Xu D. Autologous stem cell therapy in critical limb ischemia: a meta-analysis of randomized controlled trials. Stem Cells Int 2018;2018:7528464

93. Pan T, Wei Z, Fang Y, Dong Z, Fu W. Therapeutic efficacy of $\mathrm{CD}_{3} 4^{+}$cell-involved mononuclear cell therapy for no-option critical limb ischemia: a meta-analysis of random- ized controlled clinical trials. Vasc Med 2018;23:219-231

94. Gao W, Chen D, Liu G, Ran X. Autologous stem cell therapy for peripheral arterial disease: a systematic review and meta-analysis of randomized controlled trials. Stem Cell Res Ther 2019;10:140

95. Peeters Weem SM, Teraa M, de Borst GJ, Verhaar MC, Moll FL. Bone marrow derived cell therapy in critical limb ischemia: a meta-analysis of randomized placebo controlled trials. Eur J Vasc Endovasc Surg 2015;50:775783

96. Ii M, Takenaka H, Asai J, Ibusuki K, Mizukami Y, Maruyama K, Yoon YS, Wecker A, Luedemann C, Eaton E, Silver M, Thorne T, Losordo DW. Endothelial progenitor thrombospondin-1 mediates diabetes-induced delay in reendothelialization following arterial injury. Circ Res 2006;98:697-704

97. Fadini GP, Sartore S, Albiero M, Baesso I, Murphy E, Menegolo M, Grego F, Vigili de Kreutzenberg S, Tiengo A, Agostini C, Avogaro A. Number and function of endothelial progenitor cells as a marker of severity for diabetic vasculopathy. Arterioscler Thromb Vasc Biol 2006;26: 2140-2146

98. Tecilazich F, Dinh T, Pradhan-Nabzdyk L, Leal E, Tellechea A, Kafanas A, Gnardellis C, Magargee ML, Dejam A, Toxavidis V, Tigges JC, Carvalho E, Lyons TE, Veves A. Role of endothelial progenitor cells and inflammatory cytokines in healing of diabetic foot ulcers. PLoS One 2013;8:e83314

99. Zafar N, Krishnasamy SS, Shah J, Rai SN, Riggs DW, Bhatnagar A, O'Toole TE. Circulating angiogenic stem cells in type 2 diabetes are associated with glycemic control and endothelial dysfunction. PLoS One 2018;13: $\mathrm{e} 0205851$

100. Zhou B, Bi YY, Han ZB, Ren H, Fang ZH, Yu XF, Poon MC, Han ZC. G-CSF-mobilized peripheral blood mononuclear cells from diabetic patients augment neovascularization in ischemic limbs but with impaired capability. J Thromb Haemost 2006;4:993-1002

101. Losordo DW, Kibbe MR, Mendelsohn F, Marston W, Driver VR, Sharafuddin M, Teodorescu V, Wiechmann BN, Thompson C, Kraiss L, Carman T, Dohad S, Huang P, Junge CE, Story K, Weistroffer T, Thorne TM, Millay M, Runyon JP, Schainfeld R. A randomized, controlled pilot study of autologous $\mathrm{CD} 34^{+}$cell therapy for critical limb ischemia. Circ Cardiovasc Interv 2012;5:821-830

102. Klepanec A, Mistrik M, Altaner C, Valachovicova M, Olejarova I, Slysko R, Balazs T, Urlandova T, Hladikova D, Liska B, Tomka J, Vulev I, Madaric J. No difference in intra-arterial and intramuscular delivery of autologous bone marrow cells in patients with advanced critical limb ischemia. Cell Transplant 2012;21:1909-1918

103. Gu YQ, Zhang J, Guo LR, Qi LX, Zhang SW, Xu J, Li JX, Luo T, Ji BX, Li XF, Yu HX, Cui SJ, Wang ZG. Transplantation of autologous bone marrow mononuclear cells for patients with lower limb ischemia. Chin Med J (Engl) 2008;121:963-967 
104. Patiño B, Espinosa D, Solano MH, Abello V, Casas C. Morbidity and mortality associated with performing bone marrow aspiration and biopsy. Int Phys Med Rehab J 2018;3:65-70

105. Hölig K. G-CSF in healthy allogeneic stem cell donors. Transfus Med Hemother 2013;40:225-235

106. Balaguer H, Galmes A, Ventayol G, Bargay J, Besalduch J. Splenic rupture after granulocyte-colony-stimulating factor mobilization in a peripheral blood progenitor cell donor. Transfusion 2004;44:1260-1261

107. Azoulay E, Attalah H, Harf A, Schlemmer B, Delclaux C. Granulocyte colony-stimulating factor or neutrophil-induced pulmonary toxicity: myth or reality? Systematic review of clinical case reports and experimental data. Chest 2001;120:1695-1701

108. Falanga A, Marchetti $M$, Evangelista V, Manarini S, Oldani E, Giovanelli S, Galbusera M, Cerletti C, Barbui
T. Neutrophil activation and hemostatic changes in healthy donors receiving granulocyte colony-stimulating factor. Blood 1999;93:2506-2514

109. Matoba S, Tatsumi T, Murohara T, Imaizumi T, Katsuda Y, Ito M, Saito Y, Uemura S, Suzuki H, Fukumoto S, Yamamoto Y, Onodera R, Teramukai S, Fukushima M, Matsubara $\mathrm{H}$. Long-term clinical outcome after intramuscular implantation of bone marrow mononuclear cells (Therapeutic Angiogenesis by Cell Transplantation [TACT] trial) in patients with chronic limb ischemia. Am Heart J 2008;156:1010-1018

110. Onodera R, Teramukai S, Tanaka S, Kojima S, Horie T, Matoba S, Murohara T, Matsubara H, Fukushima M. Bone marrow mononuclear cells versus G-CSF-mobilized peripheral blood mononuclear cells for treatment of lower limb ASO: pooled analysis for long-term prognosis. Bone Marrow Transplant 2011;46:278-284 